\title{
The Correlation between Maternal Exposure to Air Pollution and the Risk of Orofacial Clefts in Infants: a Systematic Review and Meta-Analysis
}

\author{
Ajit Rao', Mairaj K. Ahmed ${ }^{2}$, Peter J. Taub³ ${ }^{3}$ John S. Mamoun ${ }^{4}$ \\ ${ }^{1}$ Department of Vascular Surgery, Mount Sinai Cleft \& Craniofacial Center, Icahn School of Medicine at Mount Sinai, New \\ York, USA. \\ ${ }^{2}$ Department of Dentistry/Oral and Maxillofacial Surgery, Division of Plastic Surgery, Mount Sinai Cleft \& Craniofacial \\ Center, Icahn School of Medicine at Mount Sinai, New York, USA. \\ ${ }^{3}$ Departments of Dentistry, Pediatrics, Surgery and Medical Education, Mount Sinai Cleft \& Craniofacial Center, Icahn School \\ of Medicine at Mount Sinai, New York, USA. \\ ${ }^{4}$ Private practice, Manalapan, New Jersey, USA.
}

\section{Corresponding Author:}

John Mamoun

Phone: 732-431-2888

E-mail:mamounjo@gmail.com

\begin{abstract}
Objectives: The authors performed a systematic review and meta-analysis to investigate the possible correlation between ambient air pollution and orofacial cleft anomalies in newborns.

Material and Methods: A literature search was performed using the PubMed and Google Scholar, using the keywords "air pollution", "cleft lip", "cleft palate", "carbon monoxide", "ozone", "sulfur dioxide", "nitrogen oxide", "nitrogen dioxide", and "aerodynamic diameter". Eight epidemiologic articles met the criteria of correlating either carbon monoxide (CO), ozone $\left(\mathrm{O}_{3}\right)$, nitrogen oxides $\left(\mathrm{NO}_{\mathrm{x}}\right)$, airborne particulate matter of less than $10 \mu \mathrm{m}$ in diameter $\left(\mathrm{PM}_{10}\right)$, or sulfur dioxide $\left(\mathrm{SO}_{2}\right)$ exposures with clefting of the palate alone, clefting of the lip alone, or clefting of the lip and palate. Odds ratios were extracted from the eight studies and tabulated in this meta-analysis. Quality analysis showed six high quality, one medium quality, and one low quality study.

Results: Meta-analysis of the combined data confirmed the association of $\mathrm{O}_{3}$ exposure and risk of orofacial cleft anomalies $(\mathrm{OR}=1.08 ; \mathrm{P}=0.02)$. $\mathrm{NO}_{\mathrm{x}}$ was consistently associated with decreased risk of cleft lip with or without palate and cleft palate. Conclusions: Ozone showed the strongest correlation with cleft lip and cleft palate anomalies. However, the studies overall showed an inconsistent correlation between orofacial clefts and air pollutants.
\end{abstract}

Keywords: air pollution; cleft palate; cleft lip; ozone; systematic review.

Accepted for publication: 26 March 2016

To cite this article:

Rao A, Ahmed MK, Taub PJ, Mamoun JS.

The Correlation between Maternal Exposure to Air Pollution and the Risk of Orofacial Clefts in Infants: a Systematic Review and Meta-Analysis

J Oral Maxillofac Res 2016;7(1):e2

URL: http://www.ejomr.org/JOMR/archives/2016/1/e2/v7n1e2.pdf

doi: $10.5037 /$ jomr.2016.7102 


\section{INTRODUCTION}

Cleft palate (CP), cleft lip (CL), cleft lip with or without palate $(\mathrm{CL} / \mathrm{P})$ is the most common craniofacial anomaly and the fourth most common birth defect identified in the newborn, affecting approximately 6 to 10 individuals per 1000 in the United States [1]. CP or CL is associated with speech deficits, hearing impairment, deficient mid-facial growth, severe dental malocclusion, and psychosocial dysfunction. Early treatment of these anomalies decreases long-term morbidity and decreases healthcare costs [2]. The etiologies of orofacial clefts include xenobiotic and nutrient metabolism, maternal smoking, and alcohol and drug consumption during pregnancy [3-5].

Studies have examined the adverse effects of ambient air pollutants on the fetus and newborn [6,7]. Modern pollution resulting from vehicle traffic and industrial production yields numerous ambient pollutants. Maternal exposure to such air pollution results in adverse fetal outcomes that include low birth weight, preterm birth, heart defects, congenital anomalies, infant mortality, and orofacial cleft anomalies [8-11]. Specifically, the effects of air pollutants such as nitrogen oxides $\left(\mathrm{NO}_{\mathrm{x}}\right)$, sulfur dioxide $\left(\mathrm{SO}_{2}\right)$, ozone $\left(\mathrm{O}_{3}\right)$, carbon monoxide $(\mathrm{CO})$, and particulate matter less than $10 \mu \mathrm{m}$ in diameter $\left(\mathrm{PM}_{10}\right)$ on newborn outcomes have been studied. The biologic mechanisms by which air pollutants may cause orofacial cleft anomalies are not well understood, but include mutations in fetal DNA that interfere with cellular apoptosis, anoxic events, oxidative damage, and toxicity to select fetal cell populations $[\underline{7}, \underline{12}]$.

Air pollutants inhaled in concentrated form, such as maternal smoking of tobacco products, can result in fetal anomalies such as orofacial clefts [13]. However, air pollutants in public airspaces can be diluted by the huge volume of public airspaces, and may reach a fetus only in tiny concentrations during the limited time window during gestational development when the pollutants could affect palate and lip development. Also, wind may rapidly disperse concentrated air pollutants, reducing the total number of incidents when a pregnant woman is exposed to significant concentrations of air pollutants. This meta-analysis helps to answer if diluted air pollutants such as $\mathrm{NO}_{x}$, $\mathrm{SO}_{2}, \mathrm{O}_{3}, \mathrm{CO}$ and $\mathrm{PM}_{10}$ correlate with the development of orofacial cleft anomalies in a fetus. Particular matter less than $10 \mu \mathrm{m}$ in diameter [14] was assessed in this meta-analysis for its potential correlation with orofacial cleft anomalies because it is small enough to penetrate deeply into the bronchioles of the lungs.
Particulate matter less than $2.5 \mu \mathrm{m}$ in diameter (which often originates from diesel engine exhaust) is small enough to pass from the lungs into the bloodstream and in theory reach a developing fetus.

The aim of this study was to undertake a systematic review and meta-analysis to assess the correlation between air pollutants and the development of orofacial cleft anomalies, and to determine whether air pollutant exposure is a significant risk factor for the development of orofacial cleft anomalies in the newborn.

\section{MATERIAL AND METHODS Search methods}

To identify studies that examined the correlation between ambient air pollution and clefts, a literature survey was conducted, locating studies in a date range from January 1980 to December 2012. Articles were searched using the MEDLINE search engine (National Library of Medicine), Google Scholar, and Embase by Elsevier, using terms such as "air pollution", "cleft lip", "cleft palate", "carbon monoxide", "ozone", "sulfur dioxide", "nitrogen oxide", "nitrogen dioxide", and "aerodynamic diameter." Additional articles were identified from the respective references lists of the publications identified using the three databases.

\section{Selection criteria and data collection}

Studies with quantitative data on the correlation between air pollutants and orofacial clefts were considered. From this list, articles were selected that: 1) were written in English; 2) studied exposure to $\mathrm{CO}, \mathrm{O}_{3}, \mathrm{NO}_{\mathrm{x}}, \mathrm{PM}_{10}, \mathrm{SO}_{2}$, or a combination of these; 3) studied exposure to environmental or ambient air pollution but not smoking 4) measured as outcomes CL only, CP only, or cleft lip and palate (CLP); 5) included only human subjects. Sample size was not an exclusionary criteria in the present search, although all of the studies utilized large population cohorts, presumably because investigators believed that large cohorts were needed to detect correlations between air pollution and frequency of orofacial cleft anomalies and to reduce the bias that confounding variables may have had on the frequency of orofacial cleft anomalies. Two independent reviewers analysed the selected articles to determine if articles met the inclusion criteria. Conflicts between reviewers were resolved by discussion. The data extracted from each paper included the sample size, methods and measurement, covariates, statistical analysis, and outcomes. 
A review protocol was not created as a formal written document.

\section{Quality analysis}

To assess study quality, the guidelines of Antczak et al. [15] and Jadad et al. [16] were utilized. For each study, six quality variables were evaluated: sample size, case selection, valid methodology, statistical analysis, confounding variables, and result reporting. Sample size was considered sufficient if the power of the study was at least 0.8 . Case selection quality was assessed from each study's inclusion and exclusion criteria, including whether syndromes, maternal anomalies, facial midline defects that lead to orofacial clefts, and other fetal anomalies were considered. The validity of the study methodology was based on the quality of the database used for air pollution measurement, which included the average distance from study subjects to air pollution monitoring devices, the number and density of monitoring devices, and the frequency of measurements at sites.

To assess the quality of statistical analysis, the use of appropriate models was examined for the given data, the model was considered for determining the goodness of fit, and confounding variables were analysed. Confounding variables included maternal age, ethnicity, smoking, alcohol, medications, diet, socioeconomic status, infant gender, gestational age, season of conception, and other concomitant air pollutants. The quality of results reporting was assessed by determining whether data was separated by quantitative levels of air pollutants with odds ratios and confidence intervals.

The quality of each article was ranked as low if only 2 or fewer characteristics were present, medium if 3 to 4 characteristics were present, or high if 5 to 6 characteristics were present.

\section{Data synthesis and analysis}

Statistical analysis was performed using the statistical software 'SPSS' version 18.0 (SPSS Inc., Chicago, IL, USA). Meta-analysis was conducted for each air pollutant using the odds ratios from all papers reviewed. Certain studies reported multiple odds ratios and all such ratios were included in our analysis. A fixed effects model with inverse variance was conducted to run the meta-analysis and is represented by odds ratios with confidence intervals (CI) calculated at the $95 \%$ level. P-values were twotailed with $\alpha=0.05$. Odds ratios and corresponding confidence intervals were used to construct forest plots using StatsDirect tool version 2.8.0. Combined effect is also shown on the bottom of each forestplot.

\section{RESULTS}

Figure 1 shows a flow diagram of the search result and study selection. Eight articles were identified $[12,17-23]$ that met the inclusion criteria (Table 1). Most studies were judged to be of medium or high quality. Most studies used comprehensive statistical analysis, methods, and appropriate case selection with detailed inclusion and exclusion criteria. The studies, performed in the United States, Asia, England or Australia, used large retrospective birth cohorts obtained from government birth registries, to identify a large study population of several hundred thousand people, counted the total cases of cleft anomalies (ranging from 69 to 888 among the articles), then obtained from the larger population a randomly chosen sub-population of controls that was multiple times the number of cleft cases, to obtain adequate statistical power. These studies generally used air pollutant data obtained from large networks of fixed site monitoring stations, and generally used a time period of 1 to 3 months after conception when measuring air pollutant levels, since the risk of orofacial cleft formation is highest during this period post-conception [24,25]. Most of the reviewed articles were case-control studies and measured several air pollutants, and reported an odds ratio for the development of orofacial cleft anomalies for different quartiles of air pollutant concentration.

Chung et al. [17] studied the possible correlation between the risk of orofacial clefts and sunshine, Ultra-violet radiation, $\mathrm{NO}, \mathrm{NO}_{2}$ and $\mathrm{SO}_{2}$ and $\mathrm{O}_{3}$. These variables were measured for the month of conception, and for 4 - 8 weeks post-conception, which is the approximate time period of fetal lip and palate development and fusion. Sunshine and UVR were measured due to their potential effect on pollution molecules. The authors tabulated 48,804 births occurring in Hong Kong from January, 2002 to December, 2009, locating among them 59 cleft examples. The authors consider Hong Kong to be an ideal geographic location for such a study since it is a small, densely populated city, and the population generally cannot escape pollutants there. The incidence of orofacial clefts inversely correlated with sunshine exposure in the first trimester and with $\mathrm{NO}_{x}$ at around 8 weeks post-conception, particularly for CL.

Dolk et al. [18] studied the possible association between exposure to air pollution and the risk of fourteen different congenital anomalies, including anomalies such as cardiac defects, Down syndrome, cystic kidney disease, hydrocephaly and CL or CP. 


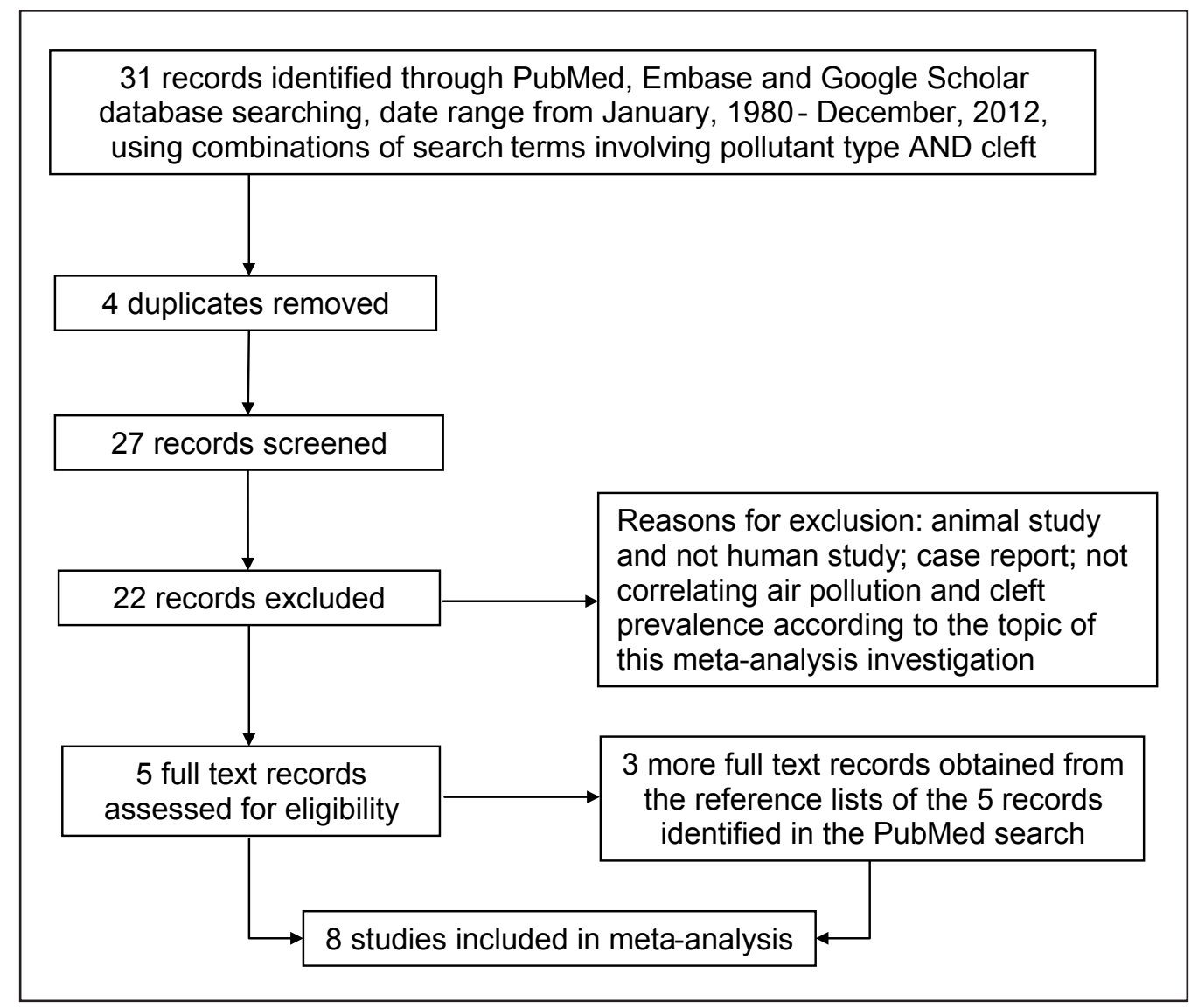

Figure 1. Flow diagram of the search result and study selection.

Table 1. Quality analysis of reviewed articles

\begin{tabular}{l|c|c|c|c|c|c|c|c}
\hline \multicolumn{1}{c|}{ Study } & $\begin{array}{c}\text { Year of } \\
\text { publication }\end{array}$ & $\begin{array}{c}\text { Sample } \\
\text { size }\end{array}$ & $\begin{array}{c}\text { Case } \\
\text { selection } \\
\text { quality }\end{array}$ & $\begin{array}{c}\text { Validity of } \\
\text { methodology }\end{array}$ & $\begin{array}{c}\text { Statistical } \\
\text { analysis } \\
\text { adequacy }\end{array}$ & $\begin{array}{c}\text { Confounding } \\
\text { variables } \\
\text { adequately } \\
\text { addressed }\end{array}$ & $\begin{array}{c}\text { Results } \\
\text { reporting }\end{array}$ & $\begin{array}{c}\text { Judged } \\
\text { quality }\end{array}$ \\
\hline Ritz et al. [12] & 2002 & + & - & + & + & + & + & High \\
\hline Chung et al. [17] & 2012 & - & + & - & + & - & - & Low \\
\hline Dolk et al. [18] & 2010 & + & + & + & + & - & + & High \\
\hline Gilboa et al. [19] & 2005 & + & + & + & + & + & + & High \\
\hline Hansen et al. [20] & 2009 & - & - & + & + & - & + & Medium \\
\hline Hwang et al. [21] & 2008 & + & - & + & + & + & + & High \\
\hline Marshall et al. [22] & 2010 & + & + & + & + & - & + & High \\
\hline Rankin et al. [23] & 2009 & - & + & + & + & + & + & High \\
\hline
\end{tabular}

The authors studied $\mathrm{NO}_{2}, \mathrm{PM}_{10}$ and $\mathrm{SO}_{2}$, but not $\mathrm{CO}$, $\mathrm{O}_{3}$ or polycyclic aromatic hydrocarbons. The authors used database mappings of estimated annual mean background $\mathrm{NO}_{2}, \mathrm{PM}_{10}$ and $\mathrm{SO}_{2}$ concentrations at a $1 \mathrm{~km}$ by $1 \mathrm{~km}$ grid resolution. From 1991 - 1999, in the cities of Southampton, London, Oxford and Newcastle, England, the authors obtained information from a database of 759,993 total births, of which there were 302 examples of $\mathrm{CP}$ and 586 examples of $\mathrm{CL} / \mathrm{P}$. The authors found no association between any pollutant and orofacial cleft anomalies.

Gilboa et al. [19] focused on studying possible associations between cardiac birth defects and air pollution exposure, but also studied the association of air pollution and risk of $\mathrm{CP}$ and $\mathrm{CL} / \mathrm{P}$. After various specified exclusions, the authors selected 4,570 cases of cardiac and cleft diagnoses among births in seven counties of Texas (USA) with at least 10,000 births per year, and selected 3,667 controls (after exclusions) from a large pool of 607,500 births in the entire state of Texas. The study found little evidence that exposure to air pollution increased the risk of cleft examples, but found a "suggested association" between $\mathrm{PM}_{10}$ and CL/P. 
Hansen et al. [20] implemented a case-control study using a population of 150,308 births occurring from January 1997 to December 2004, in Brisbane, Australia. The study correlated exposure to $\mathrm{PM}_{10}$, $\mathrm{NO}_{2}$, and $\mathrm{SO}_{2}, \mathrm{CO}$ and $\mathrm{O}_{3}$ with risk of cardiac defects and cleft defects. The authors found 302 cleft examples, that the authors matched to controls in a 5:1 ratio of controls to cleft examples. The authors found an increased risk of clefts with $\mathrm{SO}_{2}$ exposure, but a reduced risk of clefts with $\mathrm{PM}_{10}$ and $\mathrm{CO}$ exposure. However, the authors found that these results were valid only for babies born between $6-12 \mathrm{~km}$ from the air pollution monitoring sites, but were not valid for babies born between $0-6 \mathrm{~km}$ from the monitoring sites. Presumably, air pollution measurements would be more accurate the closer the subjects were to the air pollution monitor, but at these closer locations no significant results were noted. Hence, this unexpected result may be due to other unidentified sources of air pollutants such as traffic networks interspersed between monitoring stations.

Hwang et al. [21] created a case-control study that examined 721,289 Taiwanese newborns from 2001 to 2003, found 653 cases of CL/P, and selected from the larger population 6,530 controls $(10: 1$ ratio of controls to cases). The study correlated exposure to $\mathrm{SO}_{2}, \mathrm{NO}_{\mathrm{x}}, \mathrm{O}_{3}, \mathrm{CO}$, and particulate matter of 10 micrometres or less in diameter, to the risk of clefts forming during the first three months of pregnancy. The authors found that exposure to $\mathrm{O}_{3}$, but not the other pollutants, was associated with an increased cleft risk.

Marshall et al. [22] examined if there was an association between air pollution and CL, CP, or CLP. This case-control study used a population of 690,000 births, identified 717 cases of CL/P only for babies born between February, 1998 and December, 2003 , identified 12,925 controls. The study used air pollution measurements at various New Jersey, USA sites located within $40 \mathrm{~km}$ of the respective residences of birth mothers, measuring exposure to $\mathrm{CO}, \mathrm{NO}_{2}$, $\mathrm{O}_{3}, \mathrm{SO}_{2}, \mathrm{PM}_{10}$ and $\mathrm{PM}_{2.5}$. The study found that $\mathrm{CO}$ exposure reduced the risk of clefts, while exposure to $\mathrm{O}_{3}$ and $\mathrm{SO}_{2}$ was associated with a weak increase in the risk of clefts.

Rankin et al. [23] implemented a case control study to explore the potential association between exposure of air pollution with cardiac defects, CLP, and congenital defects in several other body systems. The authors studied a population of 242,268 births in the Northern UK from 1985 to 1990 , selecting from this pool 15,000 controls. The authors used measurements of black smoke and $\mathrm{SO}_{2}$ made within $10 \mathrm{~km}$ of the residence of birth mothers, but did not find a significant increased risk of CL or palate associated with exposure to these two pollutants.

Ritz et al. [12] selected 10,649 controls from a population of 754,030 babies born within four specified counties in California, USA from July 1990 to July 1993, and included 246 examples of CP, and 630 examples of CL/P. The study correlated exposure to $\mathrm{CO}, \mathrm{NO}_{2}, \mathrm{O}_{3}$, and $\mathrm{PM}_{10}$ with risk of different kinds of cardiac defects, or with CL/P. The study design did not allow the authors to control for confounding factors such as maternal smoking, occupational exposures, vitamin supplement use, diet, and obesity. $\mathrm{CO}$ exposure had some effect on cleft risk, but no other pollutants had an effect.

Both statistically significant and insignificant results were included in this meta-analysis. Four of the reviewed studies found statistically significant evidence for an increased risk of orofacial cleft anomalies with air pollutant exposure. When considering only statistically significant results, any of the pollutants could, depending on the study, correlate with an increased risk of CL/P. Four studies found a protective relationship for pollutants and development of orofacial cleft anomalies. Most studies concluded that there was either an increased risk, or protective effect, of a particular air pollutant on the development of orofacial cleft anomalies. However, three studies were inconclusive in these regards (Table 2).

The data were pooled and a meta-analysis was conducted for each air pollutant studied (Table 3). For many air pollutants, the combined odds ratio was close to 1.00 , indicating a weak association between air pollutant exposure and development of orofacial cleft anomalies. A forest plot was created using the odds ratio from these studies for each air pollutant (Figures 2 - 11). If a study reported multiple odds ratio for an air pollutant, all outcomes were included on the graph. The combined effect from the metaanalysis is charted at the bottom.

The type of air pollutant that was positively or negatively correlated to orofacial cleft anomalies differed between most studies. None of the five pollutants always showed a correlation with $\mathrm{CP}$ or $\mathrm{CL} / \mathrm{P}$. However, $\mathrm{O}_{3}$ was associated with an increased risk of both $\mathrm{CL} / \mathrm{P}$ and $\mathrm{CP}$ in all but one study. $\mathrm{CO}$ and $\mathrm{NO}_{\mathrm{x}}$ exposures correlated with a reduced risk of orofacial clefts, which is an unexpected result, given the reported associations of $\mathrm{CO}$ and $\mathrm{NO}_{x}$ with other fetal anomalies [8]. However, this negative correlation may represent a type I error [20]. $\mathrm{O}_{3}$ (increased risk) and $\mathrm{CO}$ (decreased risk) were the only air pollutants to have combined odds ratios that reached statistical significance in our meta-analysis (Table 4). 
Table 2. Summary of reviewed articles, showing outcomes for cleft palate (CP), cleft lip (CL) and cleft lip with or without palate (CL/P)

\begin{tabular}{|c|c|c|c|c|c|c|c|}
\hline Authors & Location & Date & Type & $\begin{array}{c}\text { Pollutants } \\
\text { measured }\end{array}$ & $\begin{array}{l}\text { Number } \\
\text { of cases }\end{array}$ & Outcomes $^{a}$ & Conclusion \\
\hline $\begin{array}{l}\text { Ritz et al. } \\
{[12]}\end{array}$ & $\begin{array}{l}\text { California, } \\
\text { USA }\end{array}$ & $1987-1993$ & \begin{tabular}{c|} 
Case/ \\
control
\end{tabular} & $\mathrm{CO}, \mathrm{O}_{3}$ & $\begin{array}{c}\text { CP: } 189 \\
\text { CL/P: } 450\end{array}$ & $\begin{array}{l}\mathrm{CP} \text { and } \mathrm{CO}\left(3^{\text {rd }} \text { month }\right): \\
\mathrm{OR}=0.71 ; 95 \% \mathrm{CI}: 0.52-0.95\end{array}$ & $\begin{array}{l}\text { Inconclusive for orofacial } \\
\text { clefts }\end{array}$ \\
\hline $\begin{array}{l}\text { Chung et al. } \\
{[17]}\end{array}$ & Hong Kong & $2002-2009$ & $\begin{array}{c}\text { Case/ } \\
\text { control }\end{array}$ & $\mathrm{NO}_{\mathrm{x}}, \mathrm{O}_{3}, \mathrm{SO}_{2}$ & $\begin{array}{c}\text { CP: } 12 \\
\text { CL/P: } 47\end{array}$ & $\begin{array}{l}\mathrm{CL} \text { and } \mathrm{NO}_{\mathrm{x}}:-0.9(\mathrm{P}=0.018) \\
\mathrm{CL} / \mathrm{P} \text { and } \mathrm{NO}:-0.699(\mathrm{P}=0.031)\end{array}$ & $\begin{array}{l}\text { Protective effect of } \mathrm{NO}_{\mathrm{x}} \\
\text { on } \mathrm{CL} \text { and } \mathrm{NO} \text { on } \mathrm{CL} / \mathrm{P}\end{array}$ \\
\hline $\begin{array}{l}\text { Dolk et al. } \\
{[18]}\end{array}$ & England & $1991-1999$ & Cohort & \begin{tabular}{|}
$\mathrm{NO}_{2}, \mathrm{PM}_{10}$ \\
$\mathrm{SO}_{2}$ \\
\end{tabular} & $\begin{array}{c}\text { CP: } 302 \\
\text { CL/P: } 586 \\
\end{array}$ & None & No consistent conclusions \\
\hline $\begin{array}{l}\text { Gilboa et al. } \\
{[19]}\end{array}$ & Texas, USA & $1997-2000$ & $\begin{array}{c}\text { Case/ } \\
\text { control }\end{array}$ & $\begin{array}{c}\mathrm{CO}, \mathrm{NO}_{2}, \mathrm{O}_{3}, \\
\mathrm{SO}_{2}, \mathrm{PM}_{10}\end{array}$ & $\begin{array}{c}\text { CP: } 106 \\
\text { CL/P: } 293\end{array}$ & $\begin{array}{l}\mathrm{CL} / \mathrm{P} \text { and } \mathrm{PM}_{10}\left(23.8-<29 \mathrm{mcg} / \mathrm{m}^{3}\right): \\
\mathrm{OR}=1.45 ; 95 \% \text { CI: } 1.01-2.07\end{array}$ & $\begin{array}{l}\text { Limited risk of orofacial } \\
\text { clefts from air pollutants }\end{array}$ \\
\hline $\begin{array}{l}\text { Hansen et al. } \\
{[20]}\end{array}$ & Australia & $1998-2004$ & $\begin{array}{c}\text { Case/ } \\
\text { control }\end{array}$ & $\begin{array}{l}\mathrm{CO}, \mathrm{NO}_{2}, \mathrm{O}_{3} \\
\mathrm{PM}_{10}, \mathrm{SO}_{2}\end{array}$ & $\begin{array}{l}\text { CP: } 100 \\
\text { CL/P: } 145 \\
\end{array}$ & $\begin{array}{l}\mathrm{CL} / \mathrm{P} \text { and } \mathrm{SO}_{2}: \\
\mathrm{OR}=1.27 ; 95 \% \mathrm{CI}: 1.01-1.62 \\
\mathrm{CP} \text { and } \mathrm{PM}_{10}: \\
\mathrm{OR}=0.69 ; 95 \% \mathrm{CI}: 0.5-0.93 \\
\mathrm{CL} / \mathrm{P} \text { and } \mathrm{CO}: \\
\mathrm{OR}=0.59 ; 95 \% \mathrm{CI}: 0.42-0.8\end{array}$ & $\begin{array}{l}\mathrm{SO}_{2} \text { increases risk of } \\
\mathrm{CL} / \mathrm{P} ; \\
\mathrm{PM}_{10} \text { protects against } \mathrm{CP} ; \\
\mathrm{CO} \text { protects against } \mathrm{CL} / \mathrm{P}\end{array}$ \\
\hline $\begin{array}{l}\text { Hwang et al. } \\
\text { [21] }\end{array}$ & Taiwan & $2001-2003$ & $\begin{array}{c}\text { Case/ } \\
\text { control }\end{array}$ & $\begin{array}{l}\mathrm{CO}, \mathrm{NO}_{\mathrm{x}}, \mathrm{O}_{3}, \\
\mathrm{PM}_{10}, \mathrm{SO}_{2}\end{array}$ & CL/P: 653 & $\begin{array}{l}\mathrm{CL} / \mathrm{P} \text { and } \mathrm{O}_{3}(16.6 \mathrm{ppb}-45.1 \mathrm{ppb}): \\
1^{\text {st }} \text { month: } \\
\text { OR }=1.2 ; 95 \% \mathrm{CI}: 1.02-1.39 \\
2^{\text {nd }} \text { month: } \\
\text { OR }=1.25 ; 95 \% \mathrm{CI}: 1.03-1.52 \\
\text { Three-pollution model: } \\
1^{\text {st }} \text { month: } \\
\text { OR }=1.18-1.2 ; 95 \% \text { CI: } 1.01-1.41 \\
2^{\text {nd }} \text { month: } \\
\text { OR }=1.21-1.25 ; 95 \% \text { CI: } 1.03-1.56\end{array}$ & $\begin{array}{l}\text { Increased risk of } \mathrm{CL} / \mathrm{P} \\
\text { with } \mathrm{O}_{3} \text { exposure }\end{array}$ \\
\hline $\begin{array}{l}\text { Marshall et } \\
\text { al. [22] }\end{array}$ & $\begin{array}{c}\text { New Jersey, } \\
\text { USA }\end{array}$ & $1998-2003$ & $\begin{array}{c}\text { Case/ } \\
\text { control }\end{array}$ & $\begin{array}{c}\mathrm{CO}, \mathrm{NO}_{2}, \mathrm{O}_{3} \\
\mathrm{PM}_{10}, \mathrm{SO}_{2}\end{array}$ & $\begin{array}{c}\text { CP: } 303 \\
\text { CL/P: } 414\end{array}$ & $\begin{array}{l}\mathrm{CL} / \mathrm{P} \text { and } \mathrm{SO}_{2}(>0.007 \mathrm{ppm}) \\
\mathrm{OR}=1.6 ; 95 \% \mathrm{CI}: 1.1-2.2 \\
\mathrm{CP} \text { and } \mathrm{CO}(>1.02 \mathrm{ppm}): \\
\mathrm{OR}=0.5 ; 95 \% \mathrm{CI}: 0.3-0.7\end{array}$ & $\begin{array}{l}\text { Increased risk of CL/P } \\
\text { with } \mathrm{SO}_{2} \text { exposure; } \\
\text { Protective effect of } \mathrm{CO} \\
\text { on } \mathrm{CP}\end{array}$ \\
\hline $\begin{array}{l}\text { Rankin et al. } \\
{[23]}\end{array}$ & England & $1985-1990$ & $\begin{array}{c}\text { Case/ } \\
\text { control }\end{array}$ & $\mathrm{PM}_{4}, \mathrm{SO}_{2}$ & CL/P: 215 & None & $\begin{array}{l}\text { Limited power of study } \\
\text { with many confounders }\end{array}$ \\
\hline
\end{tabular}

anly statistically significant outcomes are included.

In this meta-analysis, there was no obvious difference in odds ratios between $\mathrm{CL} / \mathrm{P}$ versus $\mathrm{CP}$.

Other studies (too recent to include in this metaanalysis) show inconsistent associations between air pollution and CLP. Guirguis et al. [26] found a nonsignificant inverse association between $\mathrm{PM}_{2.5}$ and $\mathrm{CP}$ $\left(\mathrm{OR}=0.89 ; 95 \%\right.$ CI: 0.54, 1.46), and $\mathrm{PM}_{2.5}$ and $\mathrm{CL} / \mathrm{P}$ $(\mathrm{OR}=0.76 ; 95 \% \mathrm{CI}: 0.5,1.1)$. Tanner et. al [27] found an association between orofacial clefts and maternal exposure to benzene (a variable not studied in this meta-analysis), but no significant association between orofacial clefts and maternal exposure to $\mathrm{PM}_{2.5}$.

Zhu et al. [28] studied a cohort of 188,102 births taken from a database of electronic health records, gathered from multiple centers around the United States, that was collected by the Consortium on Safe Labor. In this cohort, 63 newborns showed $\mathrm{CP}$ and 159 newborns showed CL/P. During gestational weeks $3-8$, the authors found that $\mathrm{CO}$ exposure was associated with $\mathrm{CP}(\mathrm{OR}=2.74 ; 95 \% \mathrm{CI}: 1.62$, 4.62), as was $\mathrm{NO}_{\mathrm{x}}(\mathrm{OR}=3.64 ; 95 \% \mathrm{CI}: 1.73,7.66)$ and also $\mathrm{PM}_{2.5}(\mathrm{OR}=1.74 ; 95 \% \mathrm{CI}: 1.15,2.64)$. These odds ratios are relatively higher than the other odds ratios reported in this meta-analysis, which also reflects the inconsistent associations between maternal exposure to air pollutants and orofacial cleft development in the newborn.

\section{DISCUSSION}

In one study, an increased risk of $\mathrm{CL} / \mathrm{P}$ with $\mathrm{O}_{3}$ exposure was found for the first and second month post-conception, but not after the third month [21]. This fits with the idea that the highest risk period for exposure to air pollution is during 5 to 10 weeks after conception $[\underline{24}, \underline{25}]$. Another study found a statistically significant positive correlation between $\mathrm{CL}$, with or without palate, and $\mathrm{PM}_{10}$ exposure, in a group exposed to concentrations of $23.8-29 \mathrm{mcg} / \mathrm{m}^{3}$, but did not find this correlation in the $29 \mathrm{mcg} / \mathrm{m}^{3}$ or greater group [19]. 
Table 3. Meta-analysis of the correlation between each reviewed air pollutant type and, respectively, cleft palate only (CP) or cleft lip with or without palate $(\mathrm{CL} / \mathrm{P})$

\begin{tabular}{|c|c|c|c|c|c|c|}
\hline Included studies & $\begin{array}{c}\text { Air } \\
\text { pollutant }\end{array}$ & $\begin{array}{c}\text { Type of } \\
\text { orofacial cleft }\end{array}$ & $\begin{array}{c}\text { Number of } \\
\text { cases }\end{array}$ & $\begin{array}{l}\text { Odds } \\
\text { ratio }\end{array}$ & $\begin{array}{c}95 \% \text { confidence } \\
\text { interval }\end{array}$ & P-value ${ }^{a}$ \\
\hline $\begin{array}{l}\text { Gilboa et al. [19] } \\
\text { Hansen et al. [20] } \\
\text { Hwang et al. [21] } \\
\text { Marshall et al. [22] } \\
\text { Rankin et al. [23] }\end{array}$ & \multirow[t]{2}{*}{$\mathrm{CO}$} & $\mathrm{CL} / \mathrm{P}$ & 1,955 & 1 & $0.98-1.02$ & 0.89 \\
\hline $\begin{array}{l}\text { Ritz et al. [12] } \\
\text { Gilboa et al. [19] } \\
\text { Hansen et al. [20] } \\
\text { Marshall et al. [22] }\end{array}$ & & $\mathrm{CP}$ & 698 & 0.88 & $0.78-0.99$ & 0.03 \\
\hline $\begin{array}{l}\text { Dolk et al. [18] } \\
\text { Gilboa et al. [19] } \\
\text { Hansen et al. [20] } \\
\text { Hwang et al. [21] } \\
\text { Marshall et al. [22] }\end{array}$ & \multirow{2}{*}{$\mathrm{NO}_{\mathrm{x}}$} & $\mathrm{CL} / \mathrm{P}$ & 2,138 & 0.98 & $0.91-1.06$ & 0.66 \\
\hline $\begin{array}{l}\text { Dolk et al. [18] } \\
\text { Gilboa et al. [19] } \\
\text { Hansen et al. [20] } \\
\text { Marshall et al. [22] }\end{array}$ & & $\mathrm{CP}$ & 823 & 0.84 & $0.71-1$ & 0.04 \\
\hline $\begin{array}{l}\text { Ritz et al. [12] } \\
\text { Gilboa et al. [19] } \\
\text { Hansen et al. [20] } \\
\text { Hwang et al. [21] }\end{array}$ & \multirow{2}{*}{$\mathrm{O}_{3}$} & $\mathrm{CL} / \mathrm{P}$ & 1,955 & 1.08 & $1.01-1.16$ & 0.02 \\
\hline $\begin{array}{l}\text { Ritz et al. [12] } \\
\text { Gilboa et al. [19] } \\
\text { Hansen et al. [20] } \\
\text { Marshall et al. [22] }\end{array}$ & & $\mathrm{CP}$ & 698 & 1.08 & $0.95-1.22$ & 0.23 \\
\hline $\begin{array}{l}\text { Dolk et al. [18] } \\
\text { Gilboa et al. [19] } \\
\text { Hansen et al. [20] } \\
\text { Hwang et al. [21] } \\
\text { Marshall et al. [22] }\end{array}$ & \multirow{2}{*}{$\mathrm{PM}_{10}$} & $\mathrm{CL} / \mathrm{P}$ & 2,091 & 1 & $0.98-1.03$ & 0.76 \\
\hline $\begin{array}{l}\text { Dolk et al. [18] } \\
\text { Gilboa et al. [19] } \\
\text { Hansen et al. [20] } \\
\text { Marshall et al. [22] }\end{array}$ & & $\mathrm{CP}$ & 811 & 1.02 & $0.88-1.19$ & 0.78 \\
\hline $\begin{array}{l}\text { Dolk et al. [18] } \\
\text { Gilboa et al. [19] } \\
\text { Hansen et al. [20] } \\
\text { Hwang et al. [21] } \\
\text { Marshall et al. [22] } \\
\text { Rankin et al. [23] }\end{array}$ & \multirow[t]{2}{*}{$\mathrm{SO}_{2}$} & $\mathrm{CL} / \mathrm{P}$ & 2,306 & 1.02 & $0.92-1.11$ & 0.75 \\
\hline $\begin{array}{l}\text { Dolk et al. [18] } \\
\text { Gilboa et al. [19] } \\
\text { Hansen et al. [20] } \\
\text { Marshall et al. [22] }\end{array}$ & & $\mathrm{CP}$ & 811 & 0.99 & $0.88-1.13$ & 0.91 \\
\hline
\end{tabular}

${ }^{a}$ Meta-analysis was performed using a fixed effects model with inverse variance, with $\mathrm{P}<0.05$ considered statistically significant.

Table 4. Risk of cleft lip with or without palate (CL/P), and cleft palate only (CP), for each air pollutant

\begin{tabular}{l|c|c|c|c|c|c}
\hline \multicolumn{1}{c|}{ Study } & $\begin{array}{c}\text { Type of } \\
\text { orofacial cleft }\end{array}$ & $\mathbf{C O}$ & $\mathbf{N O}_{\mathbf{x}}$ & $\mathbf{O}_{\mathbf{3}}$ & $\mathbf{P M}_{\mathbf{1 0}}$ & $\mathbf{S O}_{\mathbf{2}}$ \\
\hline \multirow{2}{*}{ Ritz et al. [12] } & $\mathrm{CL} / \mathrm{P}$ & $\mathrm{I}$ & - & $\mathrm{I}$ & - & - \\
\cline { 2 - 7 } Chung et al. [17] & $\mathrm{CP}$ & $\mathrm{I}$ & - & $\mathrm{I}$ & - & - \\
\cline { 2 - 7 } & $\mathrm{CL} / \mathrm{P}$ & - & $\downarrow$ & - & - & - \\
\hline \multirow{2}{*}{ Dolk et al. [18] } & $\mathrm{CL} / \mathrm{P}$ & - & $\downarrow$ & - & - & - \\
\cline { 2 - 7 } & $\mathrm{CP}$ & - & $\downarrow$ & - & $\downarrow$ & $\downarrow$ \\
\hline \multirow{2}{*}{ Gilboa et al. [19] } & $\mathrm{CL} / \mathrm{P}$ & $\uparrow$ & $\downarrow$ & $\uparrow$ & $\uparrow$ & $\downarrow$ \\
\cline { 2 - 7 } & $\mathrm{CP}$ & $\uparrow$ & $\uparrow$ & $\uparrow$ & $\uparrow$ & $\uparrow$ \\
\hline \multirow{2}{*}{ Hansen et al. [20] } & $\mathrm{CL} / \mathrm{P}$ & $\downarrow$ & $\uparrow$ & $\downarrow$ & $\uparrow$ & $\uparrow$ \\
\cline { 2 - 7 } & $\mathrm{CP}$ & $\downarrow$ & $\downarrow$ & $\downarrow$ & $\downarrow$ & $\downarrow$ \\
\hline \multirow{2}{*}{ Hwang et al. [21] } & $\mathrm{CL} / \mathrm{P}$ & $\leftrightarrow$ & $\downarrow$ & $\uparrow$ & $\mathrm{I}$ & $\downarrow$ \\
\cline { 2 - 7 } & $\mathrm{CP}$ & $\leftrightarrow$ & $\downarrow$ & $\uparrow$ & $\leftrightarrow$ & $\downarrow$ \\
\hline \multirow{2}{*}{ Marshall et al. [22] } & $\mathrm{CL} / \mathrm{P}$ & $\uparrow$ & $\mathrm{I}$ & $\uparrow$ & $\mathrm{I}$ & $\uparrow$ \\
\cline { 2 - 7 } & $\mathrm{CP}$ & $\downarrow$ & $\mathrm{I}$ & $\uparrow$ & $\mathrm{I}$ & $\mathrm{I}$ \\
\hline \multirow{2}{*}{ Rankin et al. [23] } & $\mathrm{CL} / \mathrm{P}$ & - & - & - & - & $\mathrm{I}$ \\
\cline { 2 - 7 } & $\mathrm{CP}$ & - & - & - & - & - \\
\hline
\end{tabular}

I = inconsistent results; $-=$ outcome not measured; $\uparrow=$ increased; $\downarrow=$ decreased; $\leftrightarrow=$ no change 


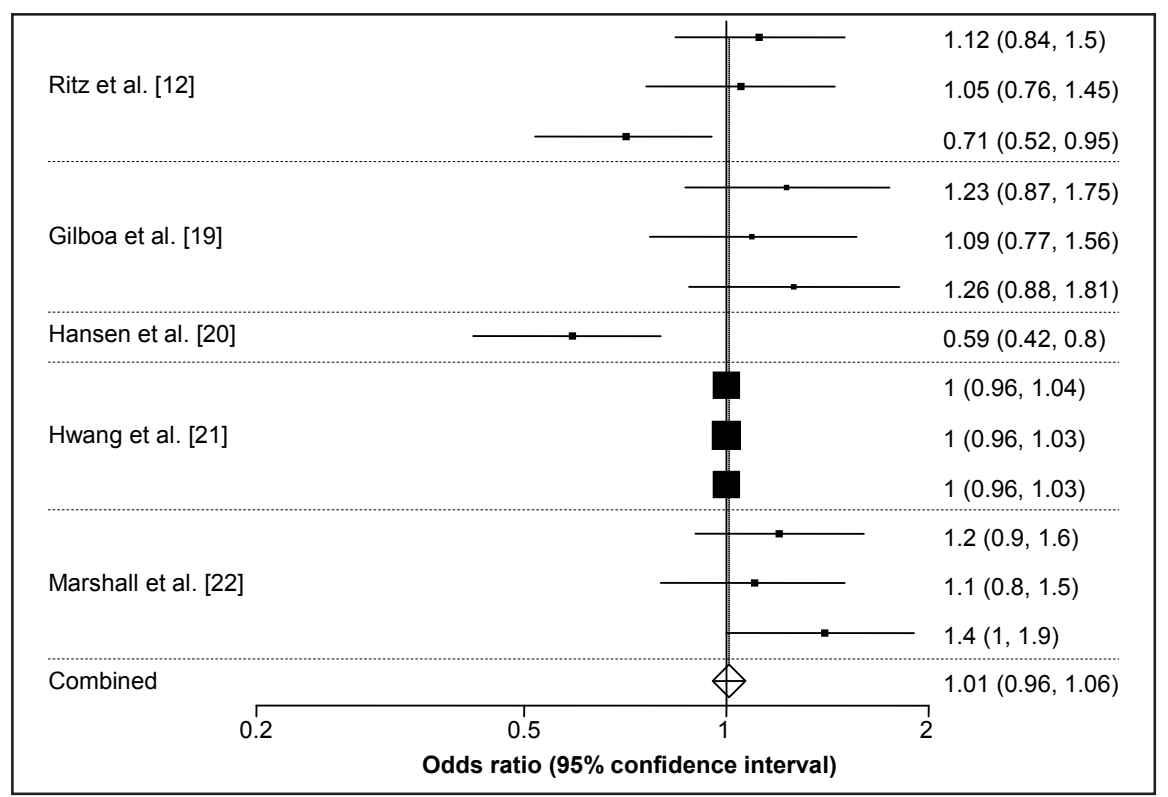

Figure 2. Forest plot for carbon monoxide and cleft lip and palate.

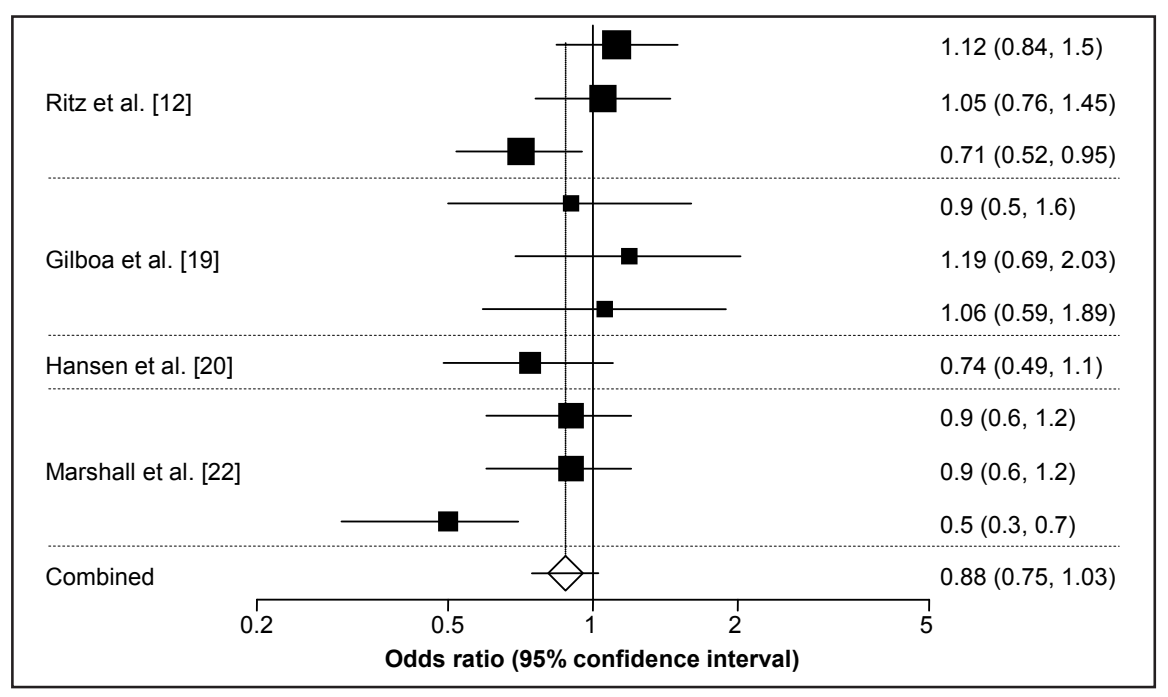

Figure 3. Forest plot for carbon monoxide and cleft palate only.

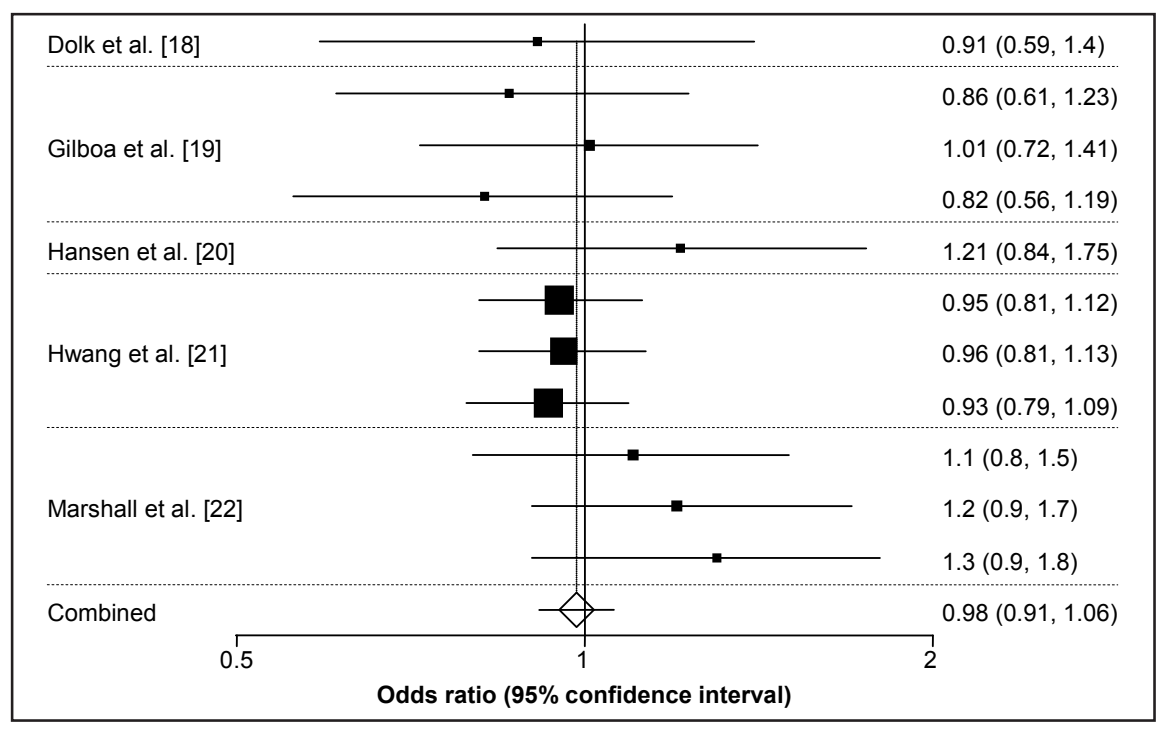

Figure 4. Forest plot for nitrogen oxides and cleft lip and palate. 


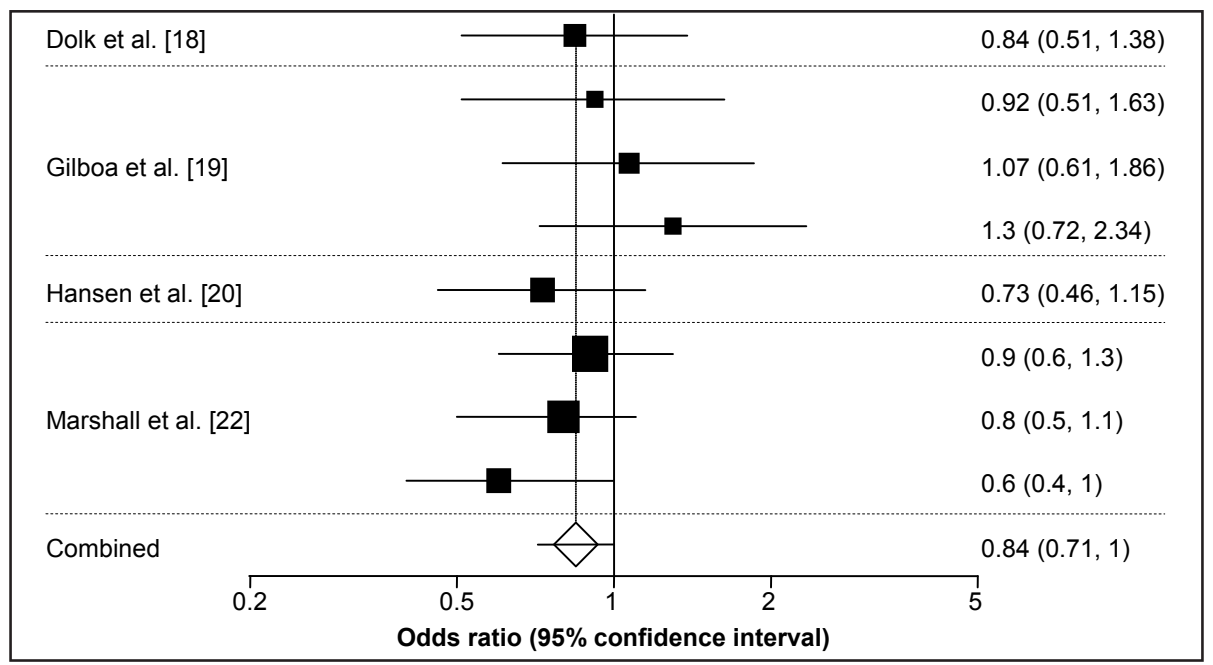

Figure 5. Forest plot for nitrogen oxides and cleft palate only.

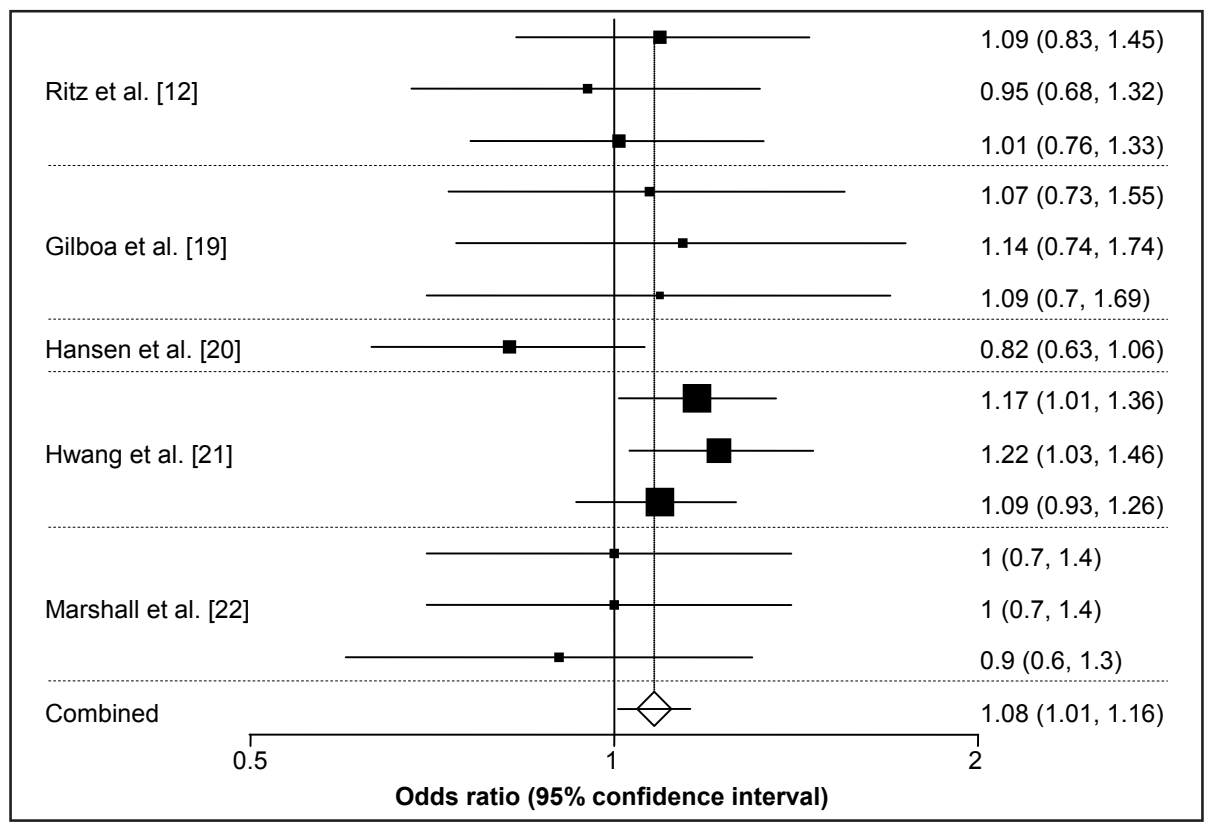

Figure 6. Forest plot for ozone and cleft lip and palate.

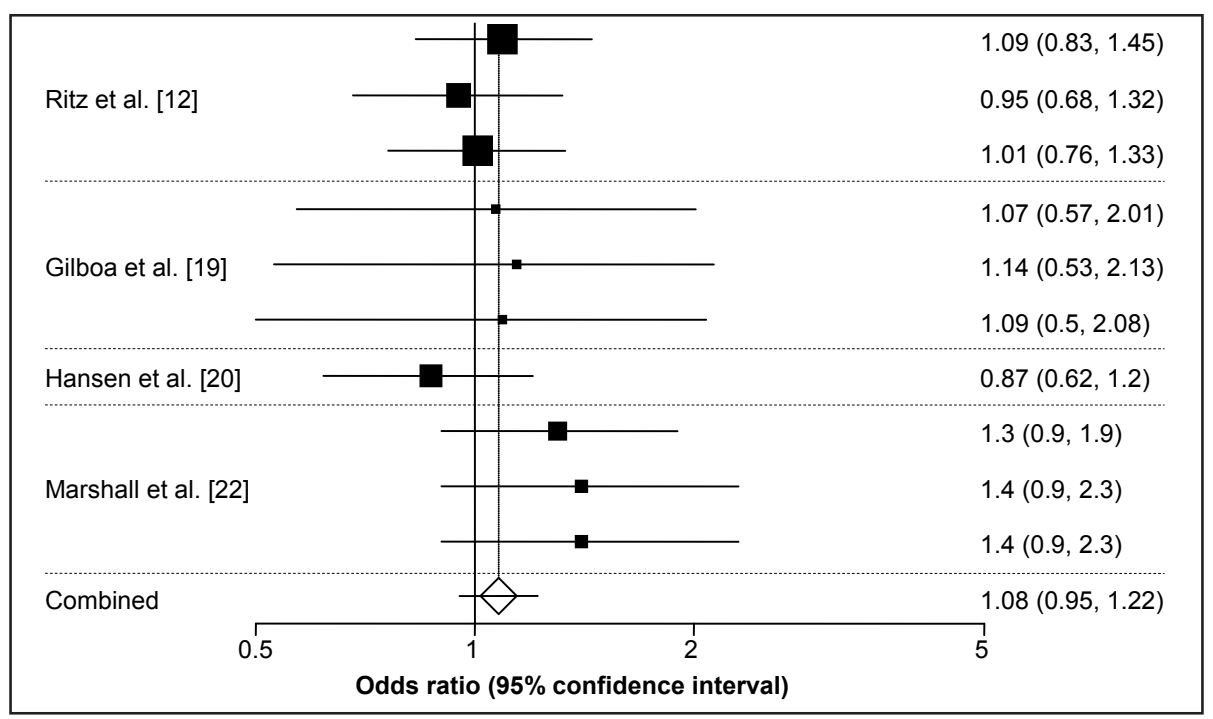

Figure 7. Forest plot for ozone and cleft palate only. 


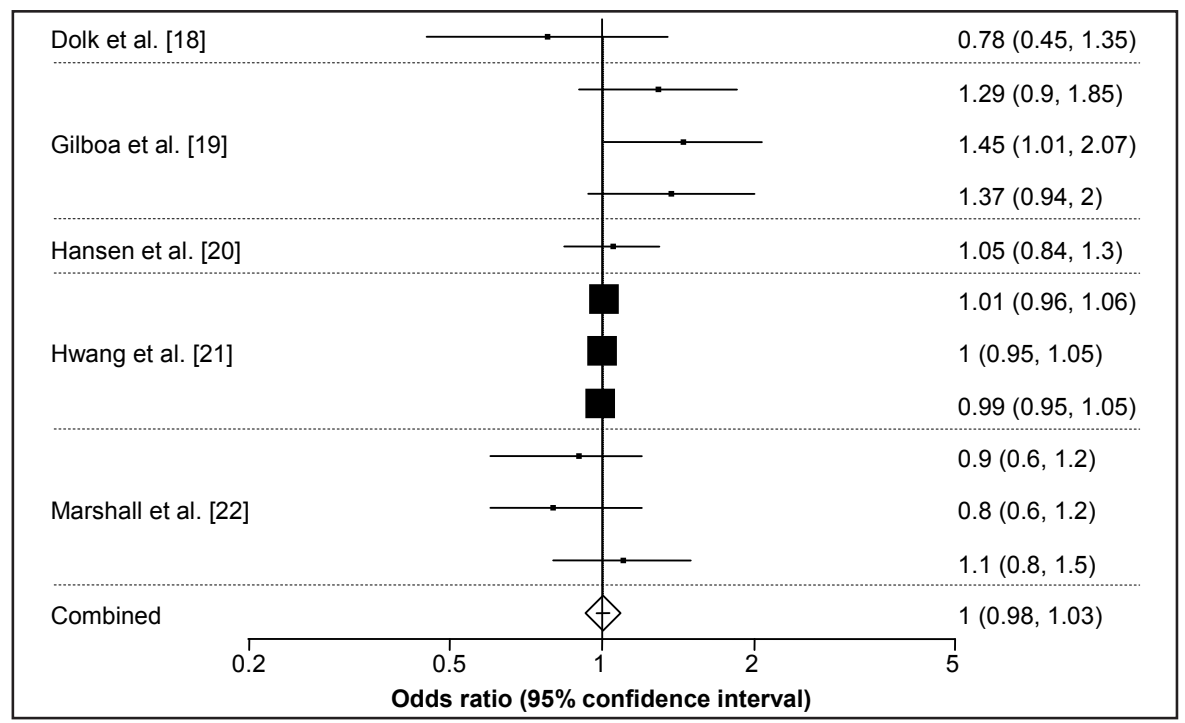

Figure 8. Forest plot for particular matter $<10 \mu \mathrm{m}$ and cleft lip and palate.

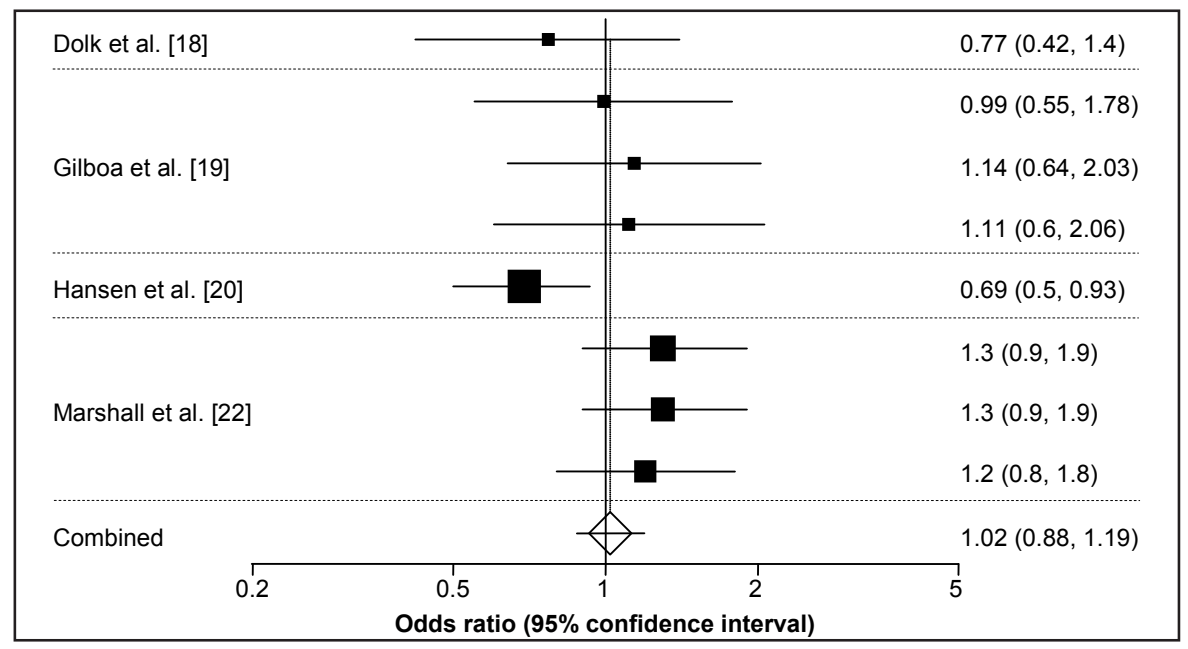

Figure 9. Forest plot for particular matter $<10 \mu \mathrm{m}$ and cleft palate only.

\begin{tabular}{|lll|}
\hline Dolk et al. [18] & $0.92(0.73,1.15)$ \\
Gilboa et al. [19] & $0.79(0.52,1.2)$ \\
$0.95(0.64,1.43)$ \\
Hwansen et al. [20]
\end{tabular}

Figure 10. Forest plot for sulfur dioxide and cleft lip and palate. 


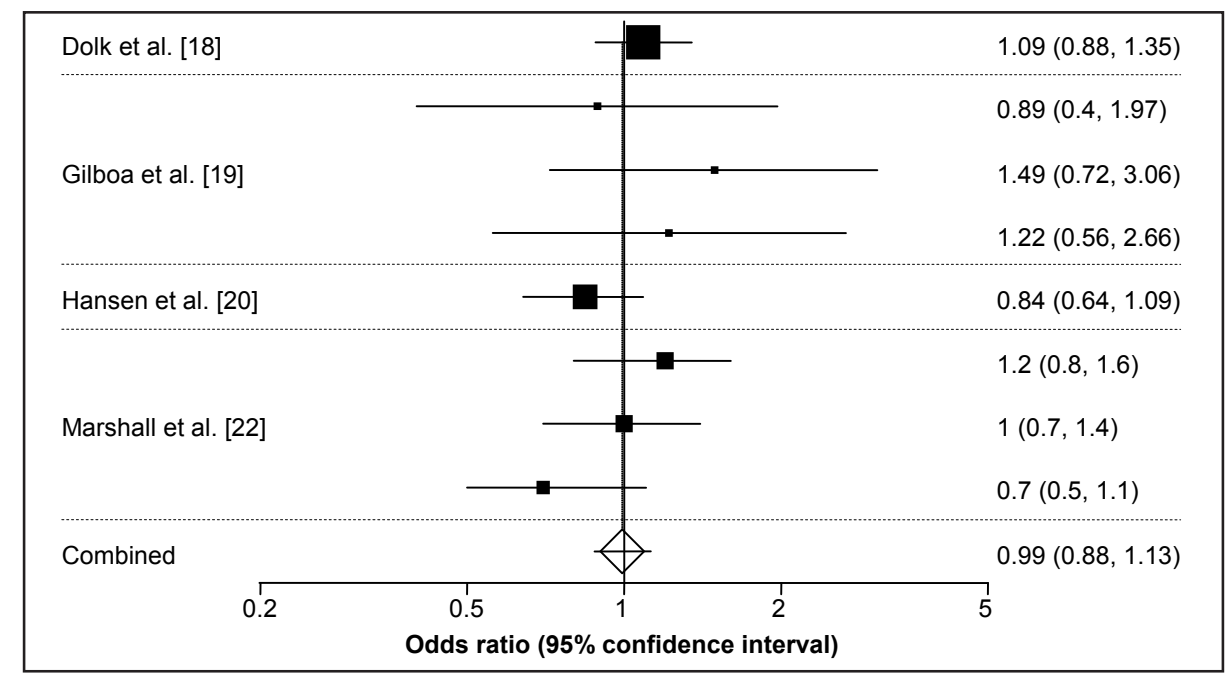

Figure 11. Forest plot for sulfur dioxide and cleft palate only.

There are several factors that could explain the inconsistency of the correlation between orofacial clefts and air pollutants. Orofacial cleft anomalies are relatively rare. Therefore, there may not have been a sufficient number of subjects in the present metaanalysis to elucidate consistent correlation trends. Also, most articles used registries to find cases and determine mothers' addresses at birth, which were then mapped and correlated to air pollution using a software program. Hence, none of the studies tracked residential mobility that may have occurred during pregnancy. Up to $32 \%$ of pregnant women may change residence between conception and birth [29]. Additionally, certain studies did not consider important confounders, including smoking, maternal age, and socioeconomic status.

In each of the reviewed articles, air pollutant levels were determined through a database, which collects information from air monitoring stations scattered throughout the area [28]. Distances from the station to homes were usually several kilometres. The studies did not account for automobile traffic and road networks interspersed between monitors and homes, the largest source of these air pollutants. Pregnant women vary in their air pollution exposure due to the amount of time pregnant women spend indoors, during travel, or through occupational exposures. Database air pollutant levels do not account for this air pollution exposure variation.

The authors suggest that future studies regarding air pollutants and orofacial clefts should account for confounders such as maternal age, paternal age, ethnicity, smoking, alcohol, medications, diet, socioeconomic status, access to prenatal care and vitamins, infant gender, multiple gestations, gestational age, season of conception, chromosomal anomalies, and other air pollutants.
Cases should be divided into CP only and CL/P to be consistent with prior studies.

Outcomes should be categorized by air pollutant level instead of time after conception as prior studies have done. When categorizing air pollutant concentration by quartile to measure outcomes, a more standardized categorization should be sought to help simplify and improve the quality of future reviews. Finally, a different method of measuring air pollutant exposure should be used in future studies. Using monitoring stations at least several kilometres away from homes while not accounting for traffic networks can significantly alter the accuracy of true air pollutant exposure. A more successful model would track individual exposure to air pollution. A recent study used backpacks carried by participants to measure air pollutant levels [30]. The authors believe that following these recommendations will improve future study quality and more thoroughly reveal the relationship between air pollutants and orofacial cleft anomalies.

\section{CONCLUSIONS}

Based on this meta-analysis, ozone was most consistently associated with an increased risk of orofacial cleft anomalies compared to other air pollutants, while carbon monoxide and nitrogen oxides correlated with a reduced risk of orofacial clefts. A consistent linear or doseresponse relationship between any one air pollutant and orofacial cleft anomalies was generally not found among the reviewed studies, indicating the need for further studies that more precisely account for confounding factors. 


\section{ACKNOWLEDGMENTS AND DISCLOSURE STATEMENTS}

The authors thank Manish Arora (Department of Preventive Medicine, Icahn School of Medicine at Mount Sinai, New York, USA) for his technical assistance while preparing this article. The authors declare no conflicts of interest related to this article, and did not utilize external funding, apart from the support of the authors' institution, during preparation of this article.

\section{REFERENCES}

1. Parker SE, Mai CT, Canfield MA, Rickard R, Wang Y, Meyer RE, Anderson P, Mason CA, Collins JS, Kirby RS, Correa A; National Birth Defects Prevention Network. Updated National Birth Prevalence estimates for selected birth defects in the United States, 2004-2006. Birth Defects Res A Clin Mol Teratol. 2010 Dec;88(12):1008-16. [Medline: 20878909] [doi: 10.1002/bdra.20735]

2. Boulet SL, Grosse SD, Honein MA, Correa-Villaseñor A. Children with orofacial clefts: health-care use and costs among a privately insured population. Public Health Rep. 2009 May-Jun;124(3):447-53. [Medline: 19445422] [PMC free article: 2663882]

3. Meyer KA, Werler MM, Hayes C, Mitchell AA. Low maternal alcohol consumption during pregnancy and oral clefts in offspring: the Slone Birth Defects Study. Birth Defects Res A Clin Mol Teratol. 2003 Jul;67(7):509-14. [Medline: 14565622] [doi: 10.1002/bdra.10057]

4. Mossey PA, Little J, Munger RG, Dixon MJ, Shaw WC. Cleft lip and palate. Lancet. 2009 Nov 21;374(9703):1773-85. [Medline: 19747722] [doi: 10.1016/S0140-6736(09)60695-4]

5. Romitti PA, Sun L, Honein MA, Reefhuis J, Correa A, Rasmussen SA. Maternal periconceptional alcohol consumption and risk of orofacial clefts. Am J Epidemiol. 2007 Oct 1;166(7):775-85. [Medline: 17609516] [doi: 10.1093/aje/kwm146]

6. Glinianaia SV, Rankin J, Bell R, Pless-Mulloli T, Howel D. Particulate air pollution and fetal health: a systematic review of the epidemiologic evidence. Epidemiology. 2004 Jan;15(1):36-45. [Medline: 14712145] [doi: 10.1097/01.ede.0000101023.41844.ac]

7. Srám RJ, Binková B, Dejmek J, Bobak M. Ambient air pollution and pregnancy outcomes: a review of the literature. Environ Health Perspect. 2005 Apr;113(4):375-82. [Medline: 15811825] [PMC free article: 1278474] [doi: 10.1289/ehp.6362]

8. Bobak M, Leon DA. Air pollution and infant mortality in the Czech Republic, 1986-88. Lanc. 1992 Oct;340(8826): 1010-4. [doi: 10.1016/0140-6736(92)93017-H]

9. Ritz B, Yu F, Chapa G, Fruin S. Effect of air pollution on preterm birth among children born in Southern California between 1989 and 1993. Epidemiology. 2000 Sep;11(5):502-11. [Medline: 10955401] [doi: 10.1097/00001648-200009000-00004]

10. Wilhelm M, Ritz B. Residential proximity to traffic and adverse birth outcomes in Los Angeles county, California, 1994-1996. Environ Health Perspect. 2003 Feb;111(2):207-16. [Medline: 12573907] [PMC free article: 1241352] [doi: 10.1289/ehp.5688]

11. Rich DQ, Demissie K, Lu SE, Kamat L, Wartenberg D, Rhoads GG. Ambient air pollutant concentrations during pregnancy and the risk of fetal growth restriction. J Epidemiol Community Health. 2009 Jun;63(6):488-96. [Medline: 19359274] [PMC free article: 4019072] [doi: 10.1136/jech.2008.082792]

12. Ritz B, Yu F, Fruin S, Chapa G, Shaw GM, Harris JA. Ambient air pollution and risk of birth defects in Southern California. Am J Epidemiol. 2002 Jan 1;155(1):17-25. [Medline: 11772780] [doi: 10.1093/aje/155.1.17]

13. Sabbagh HJ, Hassan MH, Innes NP, Elkodary HM, Little J, Mossey PA. Passive smoking in the etiology of non-syndromic orofacial clefts: a systematic review and meta-analysis. PLoS One. 2015 Mar 11;10(3):e0116963. [Medline: 25760440] [PMC free article: 4356514] [doi: 10.1371/journal.pone.0116963]

14. Thevenot PT, Saravia J, Jin N, Giaimo JD, Chustz RE, Mahne S, Kelley MA, Hebert VY, Dellinger B, Dugas TR, Demayo FJ, Cormier SA. Radical-containing ultrafine particulate matter initiates epithelial-to-mesenchymal transitions in airway epithelial cells. Am J Respir Cell Mol Biol. 2013 Feb;48(2):188-97. [Medline: 23087054] [PMC free article: 3604062] [doi: $10.1165 / \mathrm{rcmb} .2012-0052 \mathrm{OC}]$

15. Antczak AA, Tang J, Chalmers TC. Quality assessment of randomized control trials in dental research. II. Results: periodontal research. J Periodontal Res. 1986 Jul;21(4):315-21. [doi: 10.1111/j.1600-0765.1986.tb01465.x]

16. Jadad AR, Moore RA, Carroll D, Jenkinson C, Reynolds DJ, Gavaghan DJ, McQuay HJ. Assessing the quality of reports of randomized clinical trials: is blinding necessary? Control Clin Trials. 1996 Feb;17(1):1-12. [Medline: 8721797] [doi: 10.1016/0197-2456(95)00134-4]

17. Chung MK, Lao TT, Ting YH, Leung TY, Lau TK, Wong TW. Environmental factors in the first trimester and risk of oralfacial clefts in the offspring. Reprod Sci. 2013 Jul;20(7):797-803. [Medline: 23269096] [doi: 10.1177/1933719112466311]

18. Dolk H, Armstrong B, Lachowycz K, Vrijheid M, Rankin J, Abramsky L, Boyd PA, Wellesley D. Ambient air pollution and risk of congenital anomalies in England, 1991-1999. Occup Environ Med. 2010 Apr;67(4):223-7. [Medline: 19819865] [doi: 10.1136/oem.2009.045997] 
19. Gilboa SM, Mendola P, Olshan AF, Langlois PH, Savitz DA, Loomis D, Herring AH, Fixler DE. Relation between ambient air quality and selected birth defects, seven county study, Texas, 1997-2000. Am J Epidemiol. 2005 Aug 1;162(3):238-52. [Medline: 15987727] [doi: 10.1093/aje/kwi189]

20. Hansen CA, Barnett AG, Jalaludin BB, Morgan GG. Ambient air pollution and birth defects in brisbane, australia. PLoS One. 2009;4(4):e5408. [Medline: 19404385] [PMC free article: 2671139] [doi: 10.1371/journal.pone.0005408]

21. Hwang BF, Jaakkola JJ. Ozone and other air pollutants and the risk of oral clefts. Environ Health Perspect. 2008 Oct;116(10):1411-5. [Medline: 18941587] [PMC free article: 2569104] [doi: 10.1289/ehp.11311]

22. Marshall EG, Harris G, Wartenberg D. Oral cleft defects and maternal exposure to ambient air pollutants in New Jersey. Birth Defects Res A Clin Mol Teratol. 2010 Apr;88(4):205-15. [Medline: 20146378] [PMC free article: 2862481] [doi: 10.1002/bdra.20650]

23. Rankin J, Chadwick T, Natarajan M, Howel D, Pearce MS, Pless-Mulloli T. Maternal exposure to ambient air pollutants and risk of congenital anomalies. Environ Res. 2009 Feb;109(2):181-7. [Medline: 19135190] [doi: 10.1016/j.envres.2008.11.007]

24. Tolarová MM, Cervenka J. Classification and birth prevalence of orofacial clefts. Am J Med Genet. 1998 Jan 13;75(2):12637. [doi: 10.1002/(SICI)1096-8628(19980113)75:23.0.CO;2-R]

25. Sperber GH. Craniofacial embryogenesis: normal developmental mechanisms, in understanding craniofacial anomalies. Mooney MP, Siegel MI, editors. Understanding craniofacial anomalies. New York: John Wiley \& Sons, Inc.; 2002. p. 31-59. [doi: 10.1002/0471221953.ch4]

26. Girguis MS, Strickland MJ, Hu X, Liu Y, Bartell SM, Vieira VM. Maternal exposure to traffic-related air pollution and birth defects in Massachusetts. Environ Res. 2016 Apr;146:1-9. [Medline: 26705853] [PMC free article: 4761511] [doi: 10.1016/j.envres.2015.12.010]

27. Tanner JP, Salemi JL, Stuart AL, Yu H, Jordan MM, DuClos C, Cavicchia P, Correia JA, Watkins SM, Kirby RS. Associations between exposure to ambient benzene and $\mathrm{PM}(2.5)$ during pregnancy and the risk of selected birth defects in offspring. Environ Res. 2015 Oct;142:345-53. [Medline: 26196779] [doi: 10.1016/j.envres.2015.07.006]

28. Zhu Y, Zhang C, Liu D, Grantz KL, Wallace M, Mendola P. Maternal ambient air pollution exposure preconception and during early gestation and offspring congenital orofacial defects. Environ Res. 2015 Jul;140:714-20. [Medline: 26099933] [doi: 10.1016/j.envres.2015.06.002]

29. Zender R, Bachand AM, Reif JS. Exposure to tap water during pregnancy. J Expo Anal Environ Epidemiol. 2001 MayJun;11(3):224-30. [Medline: 11477520] [doi: 10.1038/sj.jea.7500163]

30. Spira-Cohen A, Chen LC, Kendall M, Lall R, Thurston GD. Personal exposures to traffic-related air pollution and acute respiratory health among Bronx schoolchildren with asthma. Environ Health Perspect. 2011 Apr;119(4):559-65. [Medline: 21216722] [PMC free article: 3080941] [doi: 10.1289/ehp.1002653]

\author{
To cite this article: \\ Rao A, Ahmed MK, Taub PJ, Mamoun JS. \\ The Correlation between Maternal Exposure to Air Pollution and the Risk of Orofacial Clefts in Infants: a Systematic Review \\ and Meta-Analysis \\ J Oral Maxillofac Res 2016;7(1):e2 \\ URL: http://www.ejomr.org/JOMR/archives/2016/1/e2/v7n1e2.pdf \\ doi: $\underline{10.5037 / j o m r .2016 .7102}$
}

Copyright (C) Rao A, Ahmed MK, Taub PJ, Mamoun JS. Published in the JOURNAL OF ORAL \& MAXILLOFACIAL RESEARCH (http://www.ejomr.org), 31 March 2016.

This is an open-access article, first published in the JOURNAL OF ORAL \& MAXILLOFACIAL RESEARCH, distributed under the terms of the Creative Commons Attribution-Noncommercial-No Derivative Works 3.0 Unported License, which permits unrestricted non-commercial use, distribution, and reproduction in any medium, provided the original work and is properly cited. The copyright, license information and link to the original publication on (http://www.ejomr.org) must be included. 